Erlend Hem (f. 1970) er dr.med. og assisterende sjefredaktør i Tidsskriftet.

\section{Kreft er ikke krig}

Få måneder før hun døde skrev journalisten Anbjørg Sætre Håtun (1972-2014) en kronikk om bruken av uttrykkene «å tape mot» eller «å vinne over» kreften (1). Å beskrive utfallet av en kreftsykdom med slike ord gir et inntrykk av at kreft er en sykdom man kan bli frisk av eller dø av hvis man er sterk eller svak. Hun syntes det var upassende. Kreft er ikke en konkurranse der man vinner eller taper på grunn av egen innsats (1).

Bruken av krigsretorikk i medisinen er ikke ny (2). Selv om det tradisjonelt har vært vanligst ved kreft, er det også brukt om en rekke andre sykdommer, som tuberkulose, aids og demens (3-5). Krig mot kreft ble lansert som begrep i mobiliseringen mot sykdommen før den annen verdenskrig i USA (6). Kreft var da en fortiet sykdom med dyster prognose. Tusenvis ble mobilisert og bidro til å bringe kreft ut i det offentlige rom. Og den amerikanske kreftforeningen ble en av de mest vellykkede frivillige organisasjonene i USA (6). I 1971 lanserte president Richard Nixon (1913-94) National Cancer Act under parolen War on cancer. Håtuns kronikk viste hvor galt det kan gå når en parole skrevet på et annet språk, fra en annen tid og ment for å mobilisere offentligheten, blir brukt som metafor på enkeltmenneskers skjebne i dagens Norge (6).

Amerikanerne har lansert en rekke kriger mot fenomener som de har ønsket å bekjempe, bl.a. War on poverty og War on drugs. Felles for disse initiativene er at de har vært mislykket. Selv om krigen mot kreft satte sykdommen på dagsordenen og dermed bidro til økt satsing på behandling, forebygging og forskning, vet vi nå at det ikke er mulig å vinne en slik krig. Vi gjør lurt i å parkere uttrykket krig mot kreft - vi kriger ikke mot naturen, som onkologen Jon Amund Kyte har minnet oss om (7).

Kreftrammedes muligheter til å påvirke forløpet av sykdommen er begrenset. Det er dokumentert at psykososiale forhold har liten betydning for kreftoverlevelsen $(8,9)$. Dette er det viktig at også pasientene vet. Det kan gi trygghet for at de selv ikke har sviktet eller tapt dersom behandlingen ikke virker eller sykdommen forverrer seg.

Psykologiske forhold har imidlertid stor betydning for hvordan livet med kreft leves, både under behandlingen og etterpå (6). Her kan det være relevant å bruke kampmetaforer. Det kan være en kamp for eksempel å følge opp krevende behandlinger eller å holde i gang familieliv og arbeid. Sætre Håtun pekte på forsoning som en løsning. Forsoning er ikke resignasjon. Det kan kreve både mot og krefter å forsone seg med det som skjer. Mange finner ikke alltid disse kreftene når sykdom og behandling tapper dem for alt overskudd. Å snakke om at det er en krig man deltar i når det som skjer er utenfor ens kontroll, er ikke nyttig (10).

Selv om krigsmetaforer bør motarbeides, må det ikke få oss til å forkaste språklige bilder i medisinen, for de kan være forløsende i mange sammenhenger (11). Det er viktig å gi plass for at pasienten gjennom egne språkbilder kan fortelle hvordan han eller hun har det. Det kan gjøre det lettere å ta opp vanskelige temaer. «Før opplevde jeg meg selv som en katedral, nå er jeg bare et nedslitt bedehus,» sa en mann i 40 -årsalderen til legen. Han hadde hatt hjerteinfarkt og var betydelig redusert (12). Slik kan pasientenes livsverden trekkes inn i konsultasjonen og gi bedre forståelse.

\section{Litteratur}

1. Håtun AS. Kreft er ikke en konkurranse. VG 16.3.2013: 42-3. www.vg.no/ nyheter/meninger/kreft-er-ikke-en-konkurranse/a/10114867 (17.11.2014).

2. Hodgkin P. Medicine is war: and other medical metaphors. Br Med J IClin Res Ed) 1985; 291: 1820-1.

3. Sontag S. Sykdom som metafor: et essay om holdninger til sykdom og død i vårt samfunn. Oslo: Gyldendal, 1979. www.nb.no/nbsok/nb/4f69939ca8a0ce3bcae9bc 92702f8f99?index=0\#0 (17.11.2014).

4. Wiggins NM. Stop using military metaphors for disease. BMJ 2012; 345: e4706.

5. Lane HP, McLachlan S. Philip J. The war against dementia: are we battle weary yet? Age Ageing 2013; 42: $281-3$.

Loge JH. Språk og kreft. VG 21.3.2013: 29.

7. Kyte JA. Kreftgåten er utgått på dato. Tidsskr Nor Legeforen 2013; 133: 1907

8. Nakaya N. Effect of psychosocial factors on cancer risk and survival. J Epidemiol 2014; 24: 1-6.

9. Nakaya N, Bidstrup PE, Saito-Nakaya K et al. Personality traits and cancer risk and survival based on Finnish and Swedish registry data. Am J Epidemiol 2010; 172: 377-85

10. McCartney M. The fight is on: military metaphors for cancer may harm patients. BMJ 2014; 349: g5155.

11. Reisfield GM, Wilson GR. Use of metaphor in the discourse on cancer. J Clin Oncol 2004; 22: 4024-7.

12. Kamps H. Pasienten som tekst - metaforer i medisinen. Tidsskr Nor Lægeforen 1999; 119: 2677-80. 